\title{
Anticancer activity of Helicia nilagirica bedd in mice transplanted with Dalton's lymphoma
}

\begin{abstract}
Cancer afflicts everyone and is a dreaded disease as it does not have definite cure, especially for solid tumors in the advanced stages of maligncies. Modern chemotherapeutic regimens are known to induce adverse toxic side effects in the patients undergoing chemotherapy indicating the need to search newer treatment modalities which are less toxic and would cure cancer. The toxic effects of different extracts of Helicia nilagirica were studied by determining the acute toxicity in normal Swiss albino mice, where mice were injected with different doses of the chloroform, ethanol and aqueous extracts of Helicia nilagirica intraperitoneally. The LD50 was found to be $2 \mathrm{~g} / \mathrm{kg} \mathrm{b}$. wt. for chloroform and $0.75 \mathrm{~g} / \mathrm{kg} \mathrm{b}$. wt. for aqueous extract, whereas the ethanol extract was nontoxic up to a dose of $2 \mathrm{~g} / \mathrm{kg}$ b. wt. The estimation of anticancer activity of Helicia nilagirica in the Dalton's lymphoma tumor bearing mice showed that administration of $50,75,100,125,150$ or $175 \mathrm{mg} / \mathrm{kg} \mathrm{b}$. wt. aqueous extract of Helicia nilagirica resulted in a dose dependent increase in tumor free survival. The highest survival of $16.6 \%$ was observed in the mice receiving $175 \mathrm{mg}$ / $\mathrm{kg}$ b. wt. aqueous extract, where tumor free survivors were recorded beyond 120 days with an average survival time of 55 and median survival time of 86 days. The administration of different doses of ethanol extract of Helicia nilagirica also elevated the tumor free survival however only up to 38 days for $175 \mathrm{mg} / \mathrm{kg} \mathrm{b}$. wt. and no tumor free survivors were observed thereafter. The dose of $175 \mathrm{mg} / \mathrm{kg}$. b. wt. aqueous extract was chosen for further investigation as maximum tumor free survivors were observed for this dose. The analysis of micronuclei frequency showed a time dependent elevation up to $24 \mathrm{~h}$ and a decline thereafter. The apoptosis index also increased with assay time up to $36 \mathrm{~h}$ post treatment. The liver and kidney function tests did not show any significant alteration indicating that it did not exert toxic effect on these two vital organs. Our study demonstrates that Helicia nilagirica is non-toxic and increase the tumor free survival beyond 120 days by inducing DNA damage, apoptosis and necrosis in the tumor cells.
\end{abstract}

Keywords: Helicia nilagirica, Dalton's lymphoma, micronuclei, apoptosis, antioxidants
Volume II Issue 2 - 2018

\author{
Ganesh Chandra Jagetia, Jennifer Zoremsiami \\ Department of Zoology, Mizoram University, India
}

Correspondence: Ganesh Chandra Jagetia, 10, Maharana Pratap Colony, Sector-13, Hiran Magri, Udaipur-313002, India, Email gc.jagetia@gmail.com

Received: October 22, 2017 | Published: April 23, 2018

\section{Introduction}

Cancer is a multifactorial disease which gives rise to the formation of rapidly dividing abnormal cells that grow beyond their usual boundaries, and invade adjoining tissues of the body by spreading into other organs through the process of metastases. It is the second leading cause of mortality worldwide. The cancer incidence has been increasing at an alarming rate and with modern diagnostic techniques more cancer cases are coming to light than ever before. In India usually 700,000 cancer cases are diagnosed annually and the figure is suspected to increase by five folds in the year $2025 .{ }^{1}$ It is expected that $1,688,780$ new cancer cases are expected to be diagnosed out of which approximately 600,920 patients of cancer would have succumbed to death in the year 2017 in the United states alone. ${ }^{2}$

The global figure of cancer occurrence in the 2018 will be still higher. The last century has seen major advances in the understanding of the process of cancer induction and also in the treatment modalities. Despite this fact the morality rates in patients suffering from cancer has not been significantly reduced than it was is 1950 , especially for the solid neoplasia. ${ }^{2}$ Further, the current cancer therapies have shown severe side effects such as immunosuppression, organ failure and infection which cause the death of patient after recovery from cancer. ${ }^{3}$ The modern chemotherapy molecules are non-specific and they not only target neoplastic cells but also affect the normal cells equally leading to adverse effects and malfunctioning of several other organs.
This indicates that new treatment strategies need to be devised if the morality rates have to be brought down in the cancer patients.

The use of plants by human beings for the treatment of various disorders and healthcare is as old as the human civilization. There are evidences from the written record on Sumerian clay slabs dating back to about 5000 years, where plants have been used as medicine. ${ }^{4}$ Plants and natural products have provided a major source of new drugs and they have been the backbone of several chemotherapeutic drugs that are in common use to treat cancer in modern clinics. The fact is that most modern chemotherapeutic drugs have been isolated from plants/natural products before their chemical syntheses were undertaken. ${ }^{5,6}$ The earliest plant derived chemotherapeutic drugs are vinca alkaloids, which have been isolated from Cathranthus roseus. The vinca alkaloids have been reported to be active against leukemias, lymphomas, Kaposi's sarcoma, testicular tumors, lung and breast cancers, either alone or in combination with other cancer chemotherapy regimens. ${ }^{7,8}$ Similarly, many other modern chemotherapeutic agents have been isolated from plants to treat cancer in clinical situation successfully. ${ }^{9-13}$ Recently, scientists and medical professionals have shown increasing interest in this field as they recognize the true health benefits of herbal medicine, which has been playing an important role in the human healthcare since time immemorial.

Helicia nilagirica Bedd. belongs to Family: Proteaceae and it is known as Pasaltakaza in Mizo language locally. Helicia nilagirica 
grows in lowlands to montane rain forests, up to an altitude of 2,0003,350 and also along with streams and hilltops or ridges. ${ }^{14}$ Mizo tribe has found its medicinal utility and it is used by Mizos to treat gynecological disease, stomach ailments, peptic ulcers, indigestion, ulcers of mouth, and infection of the urinary tract. They also use it to treat scabies and some of the skin diseases. ${ }^{15,16} \mathrm{H}$. nilagirica fruits are used in Sikkim to provide relief in cure cough and cold. ${ }^{17}$ There has been a recent report regarding the anti-inflammatory activity of $H$. nilagirica.$^{18}$ However, the systematic scientific evaluation of medicinal properties of Helicia nilagirica, especially in the treatment of cancer are unavailable. Therefore, the present study was carried out to obtain an insight into the antineoplastic activity of Helicia nilagirica in the Swiss albino mice transplanted with Dalton's lymphoma.

\section{Materials and methods}

\section{Chemicals}

Doxorubicin was requisitioned from Getwell Pharmaceuticals, Gurgaon, India. Dimethylsulphoxide (DMSO), ethidium bromide, acridine orange, and cytochalasin B were obtained from Sigma Aldrich Chemical Co. (Kolkata, India). Potassium chloride $(\mathrm{KCl})$, was procured from SD Fine-Chem Ltd., Mumbai, India. Disodium hydrogen phosphate $\left(\mathrm{Na}_{2} \mathrm{HPO}_{4}\right)$, hydrochloric acid $(\mathrm{HCl})$, sodium chloride $(\mathrm{NaCl})$, sodium hydroxide $(\mathrm{NaOH})$, sulphuric acid $\left(\mathrm{H}_{2} \mathrm{SO}_{4}\right)$, and ammonium oxalate were supplied by Merck India Limited, Mumbai.

\section{Collection and Preparation of the Extract}

The non-infected stem bark of Helicia nilagirica Bedd. (Family: Protaeceae) was collected from Sialsuk, Aizawl District of Mizoram, India during the dry season and it was identified and authenticated by Botanical Survey of India, Shillong (BSI/ERC/Tech./Plant Ident./2016/439). The cleaned noninfected bark was chopped into small pieces, and shade dried at room temperature in the dark and ground to powder form at room temperature using an electrical grinder. The dried powder was weighed and $100 \mathrm{~g}$ of bark powder was sequentially extracted in petroleum ether, chloroform, ethanol and water in a Soxhlet apparatus. All the extracts were collected and dried by evaporating their liquid contents under reduced pressure. The dried extracts were stored at -80 until use

\section{Preparation of drug and mode of administration}

The chloroform extract (HNC) of Helicia nilagirica was dissolved in sterile physiological saline (SPS) containing $1 \% \mathrm{CMC}$, and ethanol (HNE) extract was dissolved in 5\% ethanol in SPS, whereas doxorubicin and aqueous extract (HNA) were dissolved in SPS alone. The animals were administered intraperitoneally according to their body weight.

\section{Animal care handling}

The animal care and handling were performed according to the guidelines of the INSA (Indian National Science Academy, New Delhi, India) and the World Health Organization, Geneva, Switzerland and Swiss albino mice were purchased from Pasteur Institute, Shillong, Meghalaya and India. The mice were bred before use in a controlled environment of temperature $\left(24-25^{\circ} \mathrm{C}\right), 50 \%$ humidity and light and dark (12h each) cycle. Usually 5-6 animals were housed in a sterile polypropylene cage containing saw dust (procured locally) as bedding material. Six to eight weeks old male and female Swiss albino mice weighing 20-30g were used for the experimentation. The animals were maintained on commercially available food pellets and water was given ad libitum. All animal experiments were carried out according to NIH, Bethesda, USA and Indian National Science Academy, New Delhi, India guidelines. The Institutional Animal Ethics Committee of Mizoram University approved the entire study vide letter no. MZUIAEC141513, Aizawl, India.

\section{Acute toxicity}

The acute toxicity study of all extracts was performed as per Organization for Economic Co-operation and Development (OECD-425) guidelines. The mice were selected by random sampling technique $(\mathrm{n}=10)$ for each dose of each extract of Helicia nilagirica. The animals were fasted for 18 hours (both food and water withdrawn) prior to intraperitoneal injection of different extracts of Helicia nilagirica. The control group received the vehicle/s used for dissolving the extracts. The animals were constantly monitored up to 14 days after drug treatment. If mortality was observed in 2-3 animals, then the dose administered was assigned as toxic dose. If mortality was observed in one animal, then the same dose was repeated again to confirm the toxicity. The $\mathrm{LD}_{50}$ for each extract was calculated using probit analysis.

\section{Tumor model}

Dalton's lymphoma ascites (DLA) tumor was procured from the Department of Zoology, North- Eastern Hills University, Shillong, Meghalaya, India and was maintained in 10-12weeks old mice by serial intraperitoneal transplantation of $1 \times 10^{6}$ viable tumor DLA cells per animal (in $0.25 \mathrm{ml} \mathrm{PBS}, \mathrm{pH} 7.4$ ) under an aseptic condition.

\section{Experimental}

The anticancer activity of Helicia nilagirica was assessed in the Dalton's lymphoma tumor bearing mice, which were divided into the following groups:

a. Negative control groups: This group of DLA mice received $0.01 \mathrm{ml} / \mathrm{kg}$ body weight of respective vehicle used for dissolving each extract. Each extract had its own control group.

b. DOX groups: This group of animals was injected with $0.5 \mathrm{mg} /$ $\mathrm{kg}$ body weight of doxorubicin, a standard anticancer drug and served as positive control.

c. HNE groups: This group of animals received 50, 75, 100, 125,150 or $175 \mathrm{mg} / \mathrm{kg}$ body weight of the ethanol extract of Helicia nilagirica (HNE).

d. HNA groups: The animals were injected with $50,75,100$, 125,150 or $175 \mathrm{mg} / \mathrm{kg}$ body weight of the aqueous extract of Helicia nilagirica (HNA).

\section{Anticancer activity}

The tumor bearing animals were given the above treatments once daily 1 day after tumorization of mice that was followed up to subsequent 9 days. ${ }^{19}$ The animal survival was monitored daily up to 120 days, since the survival of animals up to 120 days is approximately equivalent to 5 years in humans.$^{20}$ Each group consisted of ten animals for each extract dose. The deaths, if any, of the tumor bearing mice were recorded daily and the survival was determined. The tumor 
response was assessed by calculating median survival time (MST) and average survival time (AST). The MST and AST were calculated from the animals dying within 120 days and those surviving beyond 120 days were excluded from the study. ${ }^{19}$ The increase in median life span (\% IMLS), increase in average life span (\% IALS) and the increase in life span (\%ILS) was also calculated using the following formulae:

MST $=$ First death + Last death in the group/2.

AST $=$ Sum of animals dead on different days/Number of animals.

IMLS $(\%)=$ MST of treated mice - MST of control $x$ 100/MST of control.

IALS $(\%)=$ AST of treated mice - AST of control x 100/AST of control.

$$
\operatorname{ILS}(\%)=(\mathrm{T} / \mathrm{C} \times 100)-100
$$

Where, $\mathrm{T}$ is the mean survival time in days of treated mice and $\mathrm{C}$ is that of the control mice. The optimum dose for each extract was determined and the optimum dose as well as extract which increased the longest tumor free survivors was selected for biochemical and other assays.

\section{Micronucleus assay}

The ability of HNA to induce DNA damage in DLA cells was studied by performing a separate experiment, where $1 \times 10^{6}$ DLA cells were transplanted into $5-8$ weeks old mice and allowed to grow the tumor for 9 days. Thereafter, these animals were given a single treatment of $175 \mathrm{mg} / \mathrm{kg}$ body weight of HNA or $0.5 \mathrm{mg} / \mathrm{kg}$ body weight doxorubicin intraperitoneally. One hour after the drug/s administration each of the tumorized mouse was injected with $150 \mu \mathrm{g}$ of cytochalasin B so as to suppress cytokinesis in proliferating tumor cells. The mice were euthanized at 12, 24 and $48 \mathrm{~h}$ post-drug administration and the tumor cells were collected in individual tubes. The tumor cells were washed with ammonium chloride to lyse erythrocytes and centrifuged at 1000 $\mathrm{rpm}$. The micronuclei were prepared according to the modified method of Fenech and Morley. ${ }^{21}$ In brief; cells were washed with sterile PBS and pelleted by centrifugation at $1000 \mathrm{rpm}$ for $5 \mathrm{~min}$. The cell pellet was disturbed and subjected to mild hypotonic treatment $(0.75 \%$ ammonium oxalate) at $37^{\circ} \mathrm{C}$, centrifuged once again and the resultant cell pellet was allowed to fix in Carnoy's fixative 3:1 (Methanol: Acetic acid) overnight. The cells were centrifuged and the cell pellet was resuspended in a small volume of fixative. The cells were spread on to pre cleaned coded slides to avoid observer's bias. The cells were stained with $0.025 \%$ acridine orange in Sorensen's buffer $(\mathrm{pH} 6.8$ ) and subsequently washed twice in the buffer to remove excess stain. The slides were mounted in Sorensen's buffer and observed under a DM-2500 fluorescent microscope (Leica Microsystems, Wetzlar, Germany) equipped with 450-490nm BP filter set with excitation at $453 \mathrm{~nm}$ using a $20 \mathrm{X} \mathrm{N}$ Plan objective. Usually one thousand binucleated cells with well-preserved cytoplasm were scored for each post-treatment time in each group. The frequency of binucleate cell bearing micronuclei (MNBNC) was determined (Figure 1). The micronucleated cells were scored as described earlier. ${ }^{22,23}$

\section{Apoptosis assay}

Another experiment was conducted to investigate the ability of Helicia nilagirica to induce apoptosis in Dalton's lymphoma cells, where grouping and other conditions were exactly similar to that described for micronucleus assay except that tumor bearing mice were euthanized at 2, 12, 24 and $36 \mathrm{~h}$ post drug treatment. The apoptosis assay was carried out using acridine orange and ethidium bromide dye mix. ${ }^{24}$ The tumor cells were aspirated and washed with ammonium chloride to lyse the erythrocytes and cells were pelleted by centrifugation. The cells were washed again with sterile PBS and spread on to preclean coded slides and stained with freshly prepared ethidium bromide and acridine orange (1:1) dye mix (Sigma Aldrich Chemical Co. Bangalore, India) and observed under a DM-2500 fluorescent microscope (Leica Microsystems, Wetzlar, Germany). The number of live, necrotic and apoptotic cells were counted (Figure 2). A total of 1000 cells were counted for each slide and a total of 5000 cells were counted for each group. The apoptotic index was calculated as follows:

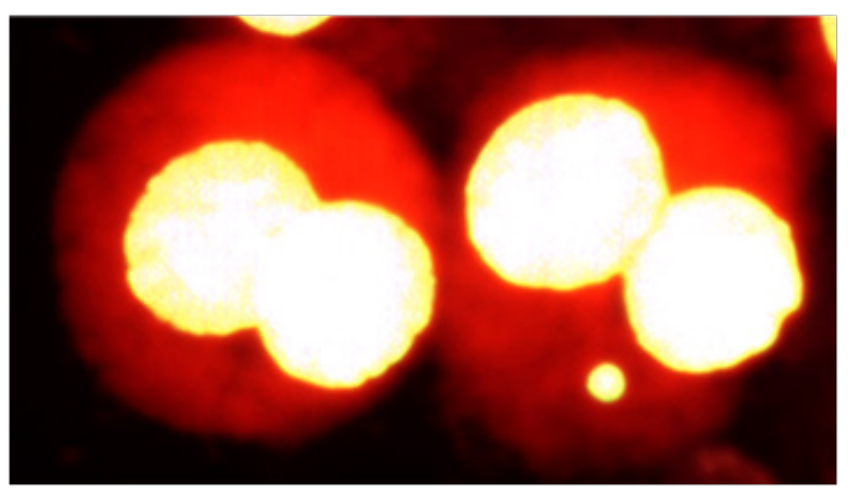

Figure I Photomicrograph of Dalton's lymphoma cells bearing micronuclei. Left image a binucleate cell and right image a binucleate cells with micronuclei.
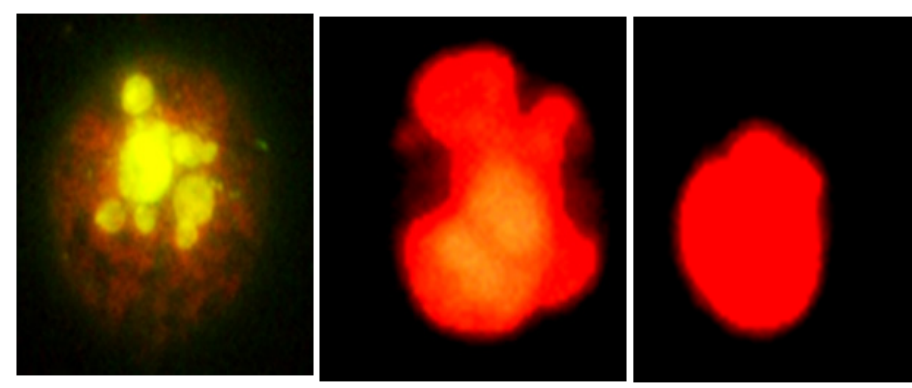

Figure 2 Photomicrograph of Dalton's lymphoma cells undergoing apoptosis and necrosis. Left:Apoptosis; Middle: Early necrosis and Right: Late necrosis.

Apoptotic index $(\%)=$ Number of apoptotic cells scored X 100/ Total number of cells counted. Liver and

\section{Collection of serum}

A separate experiment was conducted to estimate the toxicity of the HNA in the liver and kidney of the tumorized mice. The tumor bearing mice were injected with $175 \mathrm{mg} / \mathrm{kg}$ b. wt. of aqueous extract one day after transplantation of Dalton's lymphoma until nine subsequent days. After the treatment period was over, the blood was collected at different time intervals from the retro orbital sinuses using a capillary tube after anesthetizing the mice with ketamine. The collected blood was allowed to stand for $30 \mathrm{~min}$ at $4{ }^{\circ} \mathrm{C}$ so as to separate the serum. The samples were centrifuged at $1000 \mathrm{rpm}$ for $5 \mathrm{~min}$ and the serum was collected for the estimation of aspartate aminotransferase (AST), alanine aminotransferase (ALT), creatinine and uric acid at 2, 4, 6, 8,12 and 24 hours after the last drug administration. 
Commercially available kits were used to measure AST, ALT, creatinine and uric acid. The AST, ALT and alkaline phosphate (ALP), were measured with the help of commercial available Respons kits using a Respons 910 autoanalyzer (Diagnostic Systems GmbH, Holzheim, Germany).

\section{Statistical analyses}

The statistical analyses were carried out using Origin Pro 8 SRO v8.0724 (B724), Northampton, MA, USA. The significance for survival analysis was determined by Kaplan Meier test, one way ANOVA and student's ' $t$ ' test was applied for biochemical studies and followed by Tukey's post -hoc tests for multiple comparisons, wherever necessary. The Wilcoxson's signed rank test was utilized for micronucleus and apoptosis assays. The results were confirmed by repetition of the experiments. Test of homogeneity was applied to determine any statistical differences between the repeat experiments. Since no significant differences were observed the data of all experiments were combined and expressed as mean \pm standard error of the mean (SEM). A p value of $<0.05$ was considered statistically significant.

\section{Results}

The results are expressed as the mean \pm standard error of the mean (SEM), wherever required and are presented as Tables 1-7 and Figures 3-8.

Figure 3 Changes in body weight of Dalton's lymphoma bearing Swiss albino mice treated with different doses of the aqueous extract of Helicia nilagirica

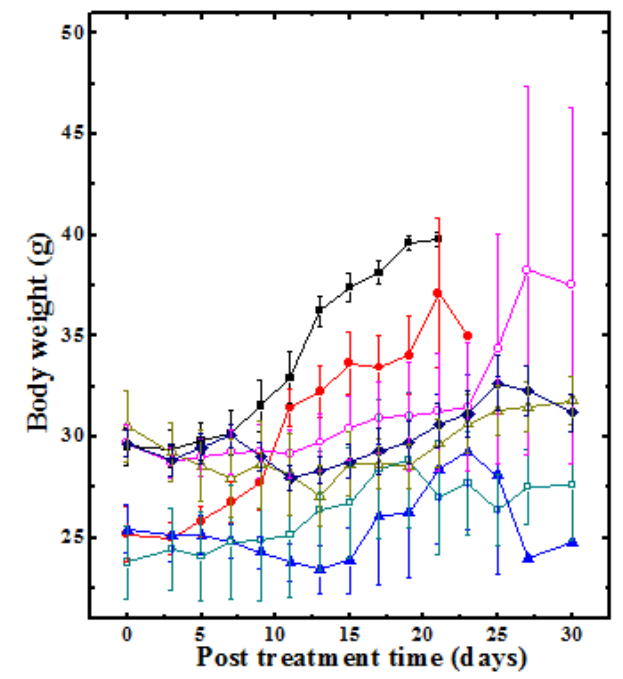

(HNA). Closed squares: SPS; Closed circles: 50mg/kg HNA; Closed triangles: $75 \mathrm{mg} / \mathrm{kg}$ HNA; Open squares: $100 \mathrm{mg} / \mathrm{kg} \mathrm{HNA}$; open circles: $125 \mathrm{mg} / \mathrm{kg} \mathrm{HNA}$; Open triangles: $150 \mathrm{mg} / \mathrm{kg}$ HNA and Diamonds: $175 \mathrm{mg} / \mathrm{kg}$ HNA. SPS: sterile physiological saline. The data are expressed as Mean \pm SEM. $N=10$.

\section{Acute toxicity}

The acute toxicity of Helicia nilagirica was determined by intraperitoneal administration of its different solvent extracts. The aqueous extract exhibited the highest toxicity with $\mathrm{LD}_{50}$ of $750 \mathrm{mg} / \mathrm{kg}$ body weight followed by chloroform extract having $\mathrm{LD}_{50}$ of $2000 \mathrm{mg}$ / $\mathrm{kg}$ body weight. However, the ethanol extract was non-toxic up to a dose of $2000 \mathrm{mg} / \mathrm{kg}$ body weight (Table 1 ).
Table I Acute toxicity of different extracts of Helicia nilagirica in Swiss albino mice after intraperitoneal administration. The LD50 has been determined using probit analysis

\begin{tabular}{llll}
\hline Extract & $\begin{array}{l}\text { Dose }(\mathrm{mg} / \mathrm{kg} \\
\text { body weight) }\end{array}$ & $\begin{array}{l}\text { Survival } \\
(\%)\end{array}$ & LD $_{\mathbf{5 0}}(\mathbf{m g} / \mathbf{k g})$ \\
\hline \multirow{4}{*}{ Chloroform } & 500 & 100 & \\
& 1000 & 100 & 2000 \\
& 1500 & 75 & \\
& 2000 & 50 & \\
& 500 & 100 & \\
Ethanol & 1000 & 100 & $>2000$ \\
& 1500 & 100 & \\
& 2000 & 100 & \\
Aqueous & 500 & 100 & \\
& 1000 & 0 & 750 \\
& 1500 & 0 & \\
\hline
\end{tabular}

$N=10$.

\section{Anticancer activity}

The DLA tumorized mice gained weight continuously due to tumor cell division and growth and there were no signs of tumor regression in the negative control group until all the animals succumbed to death. Treatment of DLA mice with 50, 75, 100, 125, 150 and 175mg/ $\mathrm{kg}$ body weight of aqueous extract of Helicia nilagirica exhibited only slight elevation in the body weight with elapse of time when compared with the negative control group (Figure 3). The comparison of Helicia nilagirica extract treated groups with negative control revealed a significant reduction in the body weight due to alleviated cell proliferation (Table 2). The administration of ethanol extract also reduced the body weight in a dose dependent manner when compared to untreated control (Table 2). However, the degree of weight reduction was lesser than HNA (Table 2).

Dalton's lymphoma transplanted in the peritoneum of mice developed rapidly with no signs of regression and all the untreated tumorized mice died within 20 days post tumor inoculation (Table 3) (Figure 4). The AST and MST for this group were 20.5 and 20.67 days, respectively (Table 3) (Figure 5). The treatment of tumor bearing mice with different doses of 50, 75, 100, 125, 150 and 175mg/ $\mathrm{kg}$ body weight of the ethanol extract resulted in a dose dependent rise in the survival and maximum number of survivors $(20 \%)$ was observed at a dose $175 \mathrm{mg} / \mathrm{kg}$ body until 40 days (Figure 4). The administration of $175 \mathrm{mg} / \mathrm{kg}$ body weight HNE resulted in an AST of 32 days leading to an increase of 12 days, whereas MST of 44.5 days leading to an increase by almost 24 days, when compared to negative control (Figure 5). The IMLS of $117.07 \%$ and an IALS of $54.88 \%$ were recorded for $175 \mathrm{mg} / \mathrm{kg} \mathrm{HNE}$ (Table 4) (Figure 5). The treatment of tumor bearing mice with different doses of 50,75,100,125, 150 and $175 \mathrm{mg} / \mathrm{kg}$ body weight of the HNA resulted in a dose dependent rise in the survival and a maximum number of survivors (16.6\%) was observed at $175 \mathrm{mg} / \mathrm{kg}$ body until 120 days and $50 \%$ of tumor free survivors were observed up to 40 days post HNA treatment (Table 4) (Figure 4). The administration of $175 \mathrm{mg} / \mathrm{kg}$ body weight HNA 
resulted in an AST of 55 days, and MST of 86 days, followed by an IMLS of $319.51 \%$ and IALS of $166.21 \%$, respectively (Table

4) (Figure 5). This dose was considered as an optimum dose and remaining experiments were conducted using this dose of HNA.

Table 2 Change in the body weight of Dalton's lymphoma bearing mice administered with different doses of ethanol or aqueous extract of Helicia nilagirica. The data are expressed as Mean \pm standard error of the mean (SEM)

\begin{tabular}{|c|c|c|c|c|c|c|c|c|}
\hline \multirow[t]{2}{*}{ Treatment } & \multirow[t]{2}{*}{$\begin{array}{l}\text { Dose (mg/ } \\
\text { kg b. wt.) }\end{array}$} & \multicolumn{7}{|c|}{ Post tumor transplanted time (Days) } \\
\hline & & 0 & 3 & 9 & 15 & 21 & 27 & 30 \\
\hline \multirow[t]{4}{*}{ SPS } & 0 & $29.52 \pm 0.93$ & $29.4 I \pm 0.93$ & $31.53 \pm 1.23$ & $37.39 \pm 0.67$ & -- & -- & -- \\
\hline & 50 & $27.42 \pm 1.05$ & $27.78 \pm 1.46$ & $29.12 \pm 2.31$ & $29.78 \pm 2.85$ & $32.91 \pm 2.46$ & -- & -- \\
\hline & 75 & $28.33 \pm 0.83$ & $26.42 \pm 0.39$ & $29.4 \pm 0.53$ & $34.09 \pm 0.91$ & $35.74 \pm 2.26$ & -- & -- \\
\hline & 100 & $27.07 \pm 0.82$ & $27.35 \pm 0.95$ & $28.08 \pm 1.08$ & $27.58 \pm 1.89$ & $27.44 \pm 2.63$ & $26.43 \pm 0.00$ & -- \\
\hline \multirow{6}{*}{ 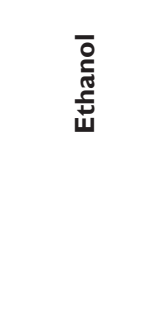 } & 125 & $24.00 \pm 0.89$ & $25.23 \pm 0.61$ & $27.53 \pm 1.59$ & $30.83 \pm 1.02$ & $35.62 \pm 0.84$ & $34.44 \pm 0.24$ & -- \\
\hline & 150 & $23.52 \pm 0.77$ & $24.23 \pm 0.27$ & $25.22 \pm 0.80$ & $26.58 \pm 0.88$ & $31.10 \pm 1.19$ & $34.76 \pm 2.11$ & $34.28 \pm 1.77$ \\
\hline & 175 & $23.47 \pm 0.66$ & $23.73 \pm 0.55$ & $26.8 \pm 0.80$ & $29.52 \pm 1.40$ & $31.99 \pm 1.81$ & $33.96 \pm 0.79$ & $34.46 \pm 1.15$ \\
\hline & 50 & $25.16 \pm 1.38$ & $24.98 \pm 0.77$ & $27.77 \pm 1.38$ & $33.65 \pm 1.53$ & $37.10 \pm 3.7$ & -- & -- \\
\hline & 75 & $25.41 \pm 1.19$ & $25.11 \pm 1.33$ & $24.28 \pm 0.79$ & $23.88 \pm 1.6 \mid$ & $28.40 \pm 3.69$ & $24.00 \pm 0.00$ & $24.80 \pm 0.00$ \\
\hline & 100 & $23.78 \pm 1.82$ & $24.4 I \pm 2.04$ & $24.91 \pm 3.06$ & $26.72 \pm 2.74$ & $27.02 \pm 2.82$ & $27.55 \pm 1.84$ & $27.60 \pm 2.70$ \\
\hline \multirow{3}{*}{ 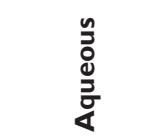 } & 125 & $29.68 \pm 0.92$ & $28.74 \pm 0.73$ & $29.28 \pm 1.28$ & $30.4 I \pm I .60$ & $31.24 \pm 2.89$ & $38.25 \pm 9.15$ & $37.50 \pm 8.8$ \\
\hline & 150 & $30.48 \pm 1.76$ & $29.21 \pm 1.45$ & $28.65 \pm 2.14$ & $28.68 \pm 1.62$ & $29.66 \pm 1.19$ & $31.5 \pm 1.22$ & $31.80 \pm 1.21$ \\
\hline & 175 & $29.67 \pm 0.64$ & $28.84 \pm 0.81$ & $29.04 \pm 0.72$ & $28.77 \pm 0.84$ & $30.58 \pm 1.10$ & $32.3 \pm 1.21$ & $31.20 \pm 0.95$ \\
\hline
\end{tabular}

$N=10$.

Table 3 Alteration in the Survival of Dalton's lymphomas bearing mice treated with various doses of different extracts of Helicia nilagirica intraperitoneally

\begin{tabular}{|c|c|c|c|c|c|c|c|c|c|c|c|c|c|}
\hline \multirow{3}{*}{$\begin{array}{l}\text { Post tumor } \\
\text { transplant } \\
\text { time } \\
\text { (day) }\end{array}$} & \multicolumn{13}{|c|}{$\begin{array}{l}\text { Survival (\%) } \\
\text { Dose (mg/kg body weight) }\end{array}$} \\
\hline & \multirow{2}{*}{$\begin{array}{l}\text { Sterile } \\
\text { physiological saline } \\
\text { (Control) } \\
0\end{array}$} & \multicolumn{6}{|c|}{ Ethanol extract } & \multicolumn{6}{|c|}{ Aqueous extract } \\
\hline & & 50 & 75 & 100 & 125 & 150 & 175 & 50 & 75 & 100 & 125 & 150 & 175 \\
\hline 0 & 100 & 100 & 100 & 100 & 100 & 100 & 100 & 100 & 100 & 100 & 100 & 100 & 100 \\
\hline 20 & 0 & 50 & 80 & 100 & 100 & 100 & 100 & 83.33 & 100 & 100 & 100 & 100 & 100 \\
\hline 24 & 0 & 0 & 20 & 40 & 60 & 100 & 100 & 16.66 & 50 & 66.66 & 71.40 & 83.33 & 100 \\
\hline 28 & 0 & 0 & 0 & 20 & 20 & 50 & 80 & 0 & 16.66 & 66.66 & 28.50 & 66.66 & 71.42 \\
\hline 30 & 0 & 0 & 0 & 0 & 0 & 30 & 60 & 0 & 0 & 50.00 & 28.50 & 50.00 & 60.00 \\
\hline 34 & 0 & 0 & 0 & 0 & 0 & 0 & 20 & 0 & 0 & 16.66 & 28.50 & 50.00 & 60.00 \\
\hline 38 & 0 & 0 & 0 & 0 & 0 & 0 & 20 & 0 & 0 & 16.66 & 28.50 & 33.33 & 50.00 \\
\hline 40 & 0 & 0 & 0 & 0 & 0 & 0 & 0 & 0 & 0 & 16.66 & 28.50 & 33.33 & 50.00 \\
\hline 44 & 0 & 0 & 0 & 0 & 0 & 0 & 0 & 0 & 0 & 0 & 28.50 & 33.33 & 32.85 \\
\hline 48 & 0 & 0 & 0 & 0 & 0 & 0 & 0 & 0 & 0 & 0 & 28.50 & 33.33 & 32.85 \\
\hline 50 & 0 & 0 & 0 & 0 & 0 & 0 & 0 & 0 & 0 & 0 & 16.66 & 33.33 & 32.85 \\
\hline 54 & 0 & 0 & 0 & 0 & 0 & 0 & 0 & 0 & 0 & 0 & 0 & 16.66 & 28.57 \\
\hline 58 & 0 & 0 & 0 & 0 & 0 & 0 & 0 & 0 & 0 & 0 & 0 & 16.66 & 28.57 \\
\hline 60 & 0 & 0 & 0 & 0 & 0 & 0 & 0 & 0 & 0 & 0 & 0 & 0 & 16.66 \\
\hline
\end{tabular}

$\mathrm{N}=10$. 
Table 4 Alteration in the survival times of Dalton's lymphoma bearing mice treated with different extracts of Helicia nilagirica.

\begin{tabular}{|c|c|c|c|c|c|}
\hline Treatment & $\begin{array}{l}\text { Dose (mg/kg } \\
\text { body weight) }\end{array}$ & MST & AST & IMLS (\%) & IALS (\%) \\
\hline $\begin{array}{l}\text { Sterile physiological } \\
\text { saline } \\
\text { (Control) }\end{array}$ & 0 & 20.5 & 20.66 & 0 & 0 \\
\hline \multirow{7}{*}{ 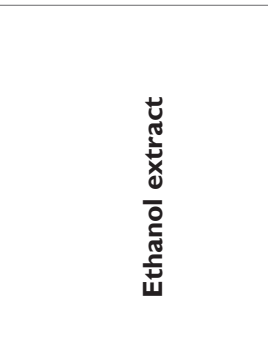 } & 50 & $24.5^{*}$ & $20.67^{*}$ & $\left.19.5\right|^{*}$ & $0.03^{*}$ \\
\hline & 75 & $33.00 *$ & $22.00 *$ & $60.97^{*}$ & $6.48^{*}$ \\
\hline & 100 & $38.00 *$ & $25.20 *$ & $85.36 *$ & $21.97^{*}$ \\
\hline & 125 & $38.50^{*}$ & $26.00 *$ & $87.80 *$ & $25.84^{*}$ \\
\hline & 150 & $44.50 *$ & $29.00 *$ & II $7.07^{*}$ & $40.36 *$ \\
\hline & 175 & $44.50^{*}$ & $32.00 *$ & II $7.07^{*}$ & $54.88^{*}$ \\
\hline & 50 & $28.50^{*}$ & $21.33^{*}$ & $39.02 *$ & $3.25^{*}$ \\
\hline \multirow{5}{*}{ 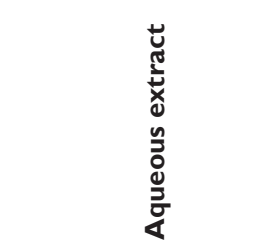 } & 75 & $32.00 *$ & $24.16^{*}$ & $56.09 *$ & $16.97 *$ \\
\hline & 100 & $80.00 *$ & $42.50 *$ & $290.24^{*}$ & $105.7 \mid *$ \\
\hline & 125 & $79.00^{*}$ & $38.00 *$ & $285.36^{*}$ & $83.93 *$ \\
\hline & 150 & $75.00^{*}$ & $55.33^{*}$ & $265.85^{*}$ & $167.82^{*}$ \\
\hline & 175 & $86.00 *$ & $55.00 *$ & $319.51 *$ & $|66.2|^{*}$ \\
\hline
\end{tabular}

$* p<0.05$, when treatment groups are compared to the spontaneous control group. $N=10$

MST, Median survival time;AST, Average survival time; IMLS, Increase in median life span; IALS, increase in average life span
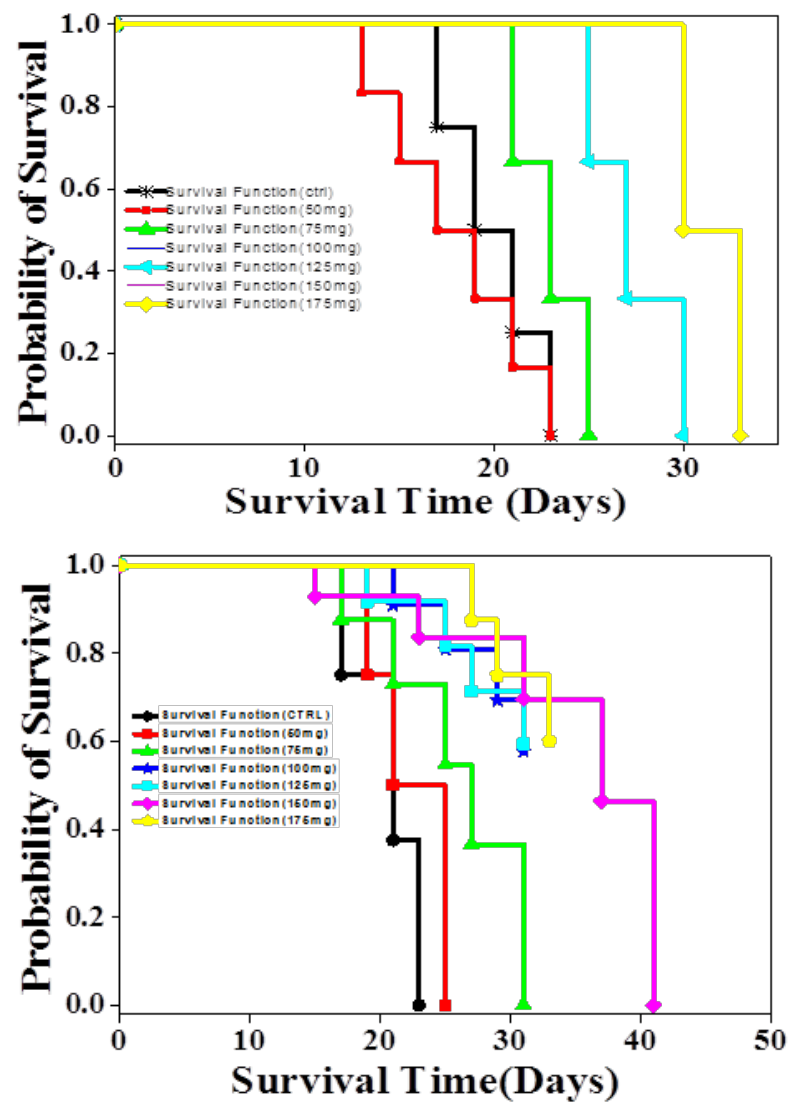

Figure 4 Effect of different doses of ethanol (Upper) and aqueous (Lower) extracts of Helicia nilagirica on the Kaplan Meir's' estimate of survival of Dalton's lymphoma ascites bearing mice. $\mathrm{N}=10$.
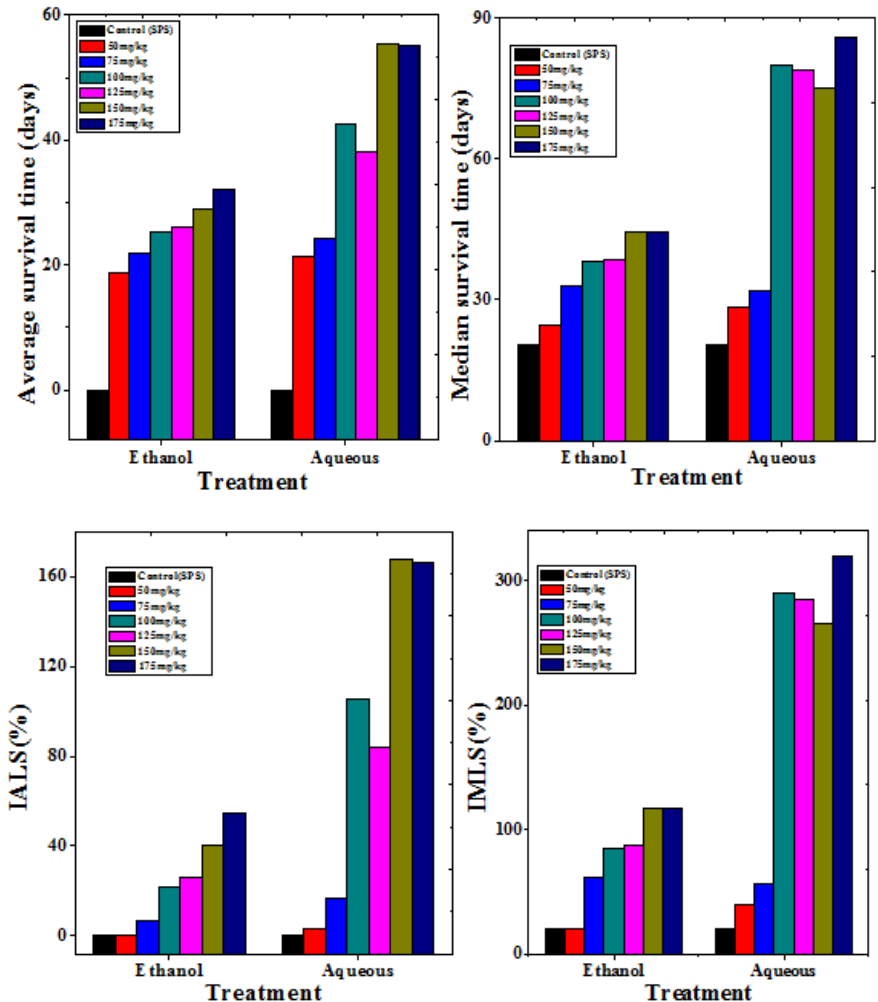

Figure 5 Effect of $175 \mathrm{mg} / \mathrm{kg}$ body weight ethanol or aqueous extract of Helicia nilagirica in Dalton's lymphoma bearing mice on the tumor response assessment based on average survival time (AST), median survival time (MST), mean life span (\% IMLS) and increase in average life span (\% IALS). $P<0.05$, when treatment groups are compared to spontaneous control group. 

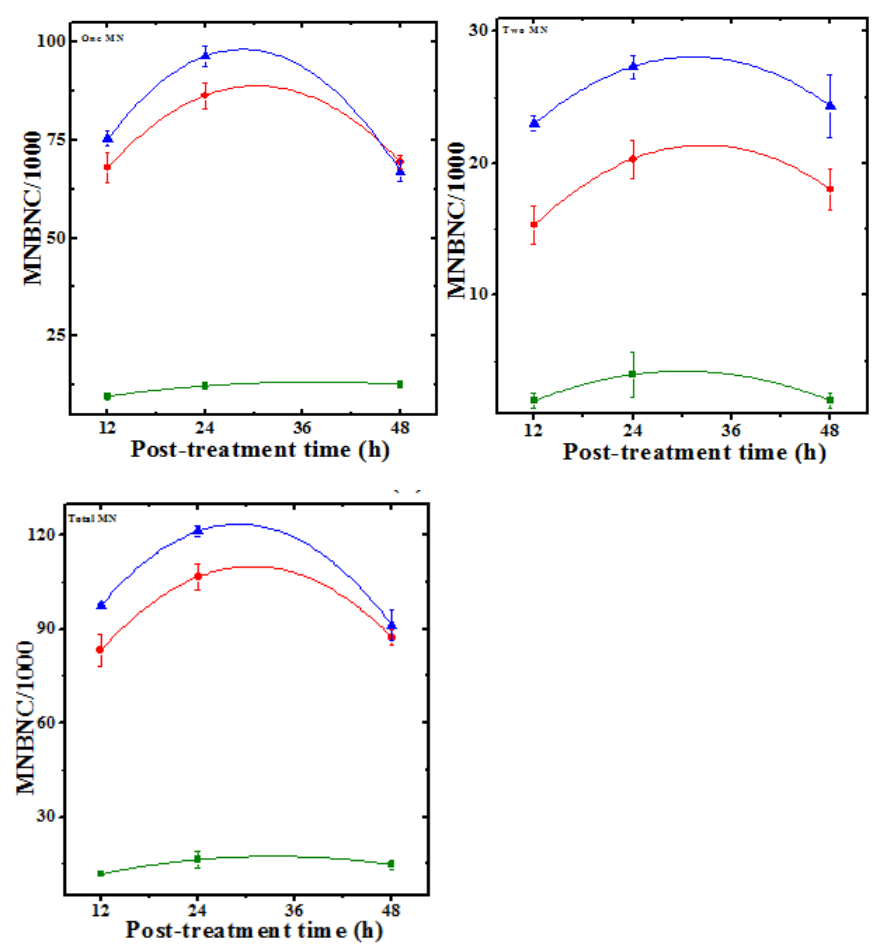

Figure $\mathbf{6}$ Induction of micronuclei in Dalton's lymphoma ascites bearing mice treated with $175 \mathrm{mg} / \mathrm{kg}$ body weight of aqueous extract of Helicia nilagirica or $0.5 \mathrm{mg} / \mathrm{kg}$ body weight of doxorubicin at different post-treatment times. Squares: Sterile physiological saline; Circles: Helicia nilagirica extract and Triangles: doxorubicin. The results are expressed as the frequency of micronucleated binucleate cells (MNBNC)/I000 cells \pm SEM. $N=10$.

\section{Micronucleus assay}

The treatment of tumor bearing mice with $175 \mathrm{mg} / \mathrm{kg}$ body weight of HNA as well as treatment with $0.5 \mathrm{mg} / \mathrm{kg}$ body weight of doxorubicin showed a significant rise in the frequency of cells bearing one and two micronuclei in the binucleate cells scored at different posttreatment times (Figure 6). The frequencies of both cells with one and two micronuclei increased with assay time up to $24 \mathrm{~h}$ post treatment and declined thereafter (Figure 6). The frequency of micronuclei was greatest at $24 \mathrm{~h}$ post treatment $(\mathrm{p}<0.05)$ (Table 5) (Figure 6).

\section{Apoptosis assay}

Treatment of DLA mice with $175 \mathrm{mg} / \mathrm{kg}$ body eight of HNA or DOX increased the apoptotic and necrotic indices in a time dependent manner and maximum number of tumor cells died due to apoptosis or necrosis by $36 \mathrm{~h}$ (Figure 7). The apoptotic and necrotic indices showed a significant $(\mathrm{p}<0.05)$ elevation when compared to negative control in the HNA and DOX treated groups (Table 6).

\section{Liver and kidney function test}

The serum level of mice treated with HNA $(175 \mathrm{mg} / \mathrm{kg}$ body weight) or DOX $(0.5 \mathrm{mg} / \mathrm{kg}$ body weight $)$ did not show any significant change in the level of aspartate aminotransferase (AST), and alanine aminotransferase (ALT) except a marginal rise at $8 \mathrm{~h}$ for HNA which was found to be within the normal range (Table 7). The uric acid and creatinine levels were also determined to test their toxic effect in the kidney, and the result did not show any significant alteration except at $12 \mathrm{~h}$ post treatment for uric acid which was also found to be within the normal range (Table 7) (Figure 8). The toxic profile for both the liver and kidney showed that there was no adverse side effect associated with the dose of HNA used for the present study.

Table 5 Frequency of micronuclei (MN) in Dalton's lymphoma ascites bearing mice treated with $175 \mathrm{mg} / \mathrm{kg}$ body weight aqueous extract of Helicia nilagirica or $0.5 \mathrm{mg} / \mathrm{kg}$ body weight doxorubicin at different post treatment time

\begin{tabular}{|c|c|c|c|c|c|c|c|c|c|}
\hline \multirow{3}{*}{$\begin{array}{l}\text { Post } \\
\text { treatment } \\
\text { time (hour) }\end{array}$} & \multicolumn{9}{|c|}{ Frequency of micronuclei (Mean \pm SEM) } \\
\hline & \multicolumn{3}{|c|}{ Sterile physiological saline } & \multicolumn{3}{|c|}{ Helicia nilagirica aqueous extract } & \multicolumn{3}{|l|}{ Doxorubicin } \\
\hline & One MN & $\begin{array}{l}\text { Two } \\
\text { MN }\end{array}$ & Total & One MN & Two MN & Total & One MN & Two MN & Total \\
\hline 12 & $9.67 \pm 0.88$ & $2 \pm 0.57$ & $11.67 \pm 0.33^{*}$ & $68.00 \pm 3.78^{*}$ & $15.33 \pm 1.45^{*}$ & $83.33 \pm 5.21^{*}$ & $75.33 \pm 1.85^{*}$ & $23.00 \pm 0.58^{*}$ & $97.67 \pm 0.67 *$ \\
\hline 24 & $12.33 \pm 0.88$ & $4 \pm 1.73$ & $16.33 \pm 2.60 *$ & $86.33 \pm 3.28 *$ & $20.33 \pm 1.45^{*}$ & $106.67 \pm 4.33^{*}$ & $96.33 \pm 2.73 *$ & $27.33 \pm 0.88 *$ & $121.33 \pm 1.76^{*}$ \\
\hline 48 & $12.67 \pm 0.88$ & $2 \pm 0.57$ & $14.67 \pm 1.33^{*}$ & $69.33 \pm 1.76 *$ & $18.00 \pm 1.53^{*}$ & $87.33 \pm 2.33^{*}$ & $67.4 \pm 2.42 *$ & $24.33 \pm 2.33^{*}$ & $91.33 \pm 4.67^{*}$ \\
\hline
\end{tabular}

$*_{p}<0.05$, when treatment groups are compared with concurrent control (SPS) group.No symbol= non-significant. $N=10$

Table 6 Induction of apoptosis and necrosis in Dalton's lymphoma ascites bearing mice treated with $175 \mathrm{mg} / \mathrm{kg}$ body weight of Helicia nilagirica or $0.5 \mathrm{mg} / \mathrm{kg}$ body weight doxorubucin at different post treatment time

\begin{tabular}{|c|c|c|c|c|c|c|}
\hline \multirow{3}{*}{$\begin{array}{l}\text { Post treatment } \\
\text { time (hour) }\end{array}$} & \multicolumn{6}{|c|}{ Apoptosis and necrosis $(\% \pm$ SEM) } \\
\hline & \multicolumn{2}{|c|}{ Sterile physiological saline } & \multicolumn{2}{|c|}{ Helicia nilagirica aqueous extract } & \multicolumn{2}{|c|}{ Doxorubucin } \\
\hline & Apoptotic & Necrotic & Apoptotic & Necrotic & Apoptotic & Necrotic \\
\hline 2 & $1.76 \pm 0.09$ & $1.38 \pm 0.08$ & $3.62 \pm 0.13^{*}$ & $2.68 \pm 0.13^{*}$ & $5.96 \pm 0.15^{*}$ & $4.48 \pm 0.13 *$ \\
\hline 12 & $2.56 \pm 0.16$ & $1.66 \pm 0.09$ & $9.62 \pm 0.15^{*}$ & $7.50 \pm 0.15^{*}$ & $13.72 \pm 0.14 *$ & $10.48 \pm 0.16 *$ \\
\hline 24 & $3.48 \pm 0.13$ & $2.26 \pm 0.09$ & $11.70 \pm 0.10 *$ & $10.44 \pm 0.15^{*}$ & $16.02 \pm 0.12 *$ & $11.34 \pm 0.09 *$ \\
\hline 36 & $4.36 \pm 0.12$ & $3.22 \pm 0.08$ & $12.28 \pm 0.10^{*}$ & $9.64 \pm 0.12 *$ & $16.90 \pm 0.07 *$ & $11.40 \pm 0.13^{*}$ \\
\hline
\end{tabular}

$*_{p}<0.05$, when treatment groups are compared with concurrent control (SPS) group. No symbol= non-significant. $\mathbf{N}=\mathbf{I} \mathbf{0}$. 
Table 7 Effect of $175 \mathrm{mg} / \mathrm{kg}$ body weight aqueous Helicia nilagirica extract or $0.5 \mathrm{mg} / \mathrm{kg}$ body weight doxorubicin on the liver and kidney functions of Dalton's lymphoma bearing mice

\begin{tabular}{|c|c|c|c|c|c|c|}
\hline \multirow[b]{2}{*}{ Treatment } & \multirow{2}{*}{$\begin{array}{l}\text { Dose } \\
\text { (mg/kg } \\
\text { b.wt.) }\end{array}$} & \multirow{2}{*}{$\begin{array}{l}\text { Post } \\
\text { treatment } \\
\text { time (h) }\end{array}$} & \multicolumn{2}{|c|}{ Liver function test } & \multicolumn{2}{|c|}{ Kidney function test } \\
\hline & & & AST (U/L) & ALT (U/L) & $\begin{array}{l}\text { Creatinine } \\
(\mathrm{mg} / \mathrm{dl})\end{array}$ & $\begin{array}{l}\text { Uric acid (mg/ } \\
\text { dl) }\end{array}$ \\
\hline \multirow{6}{*}{$\begin{array}{l}\text { Sterile } \\
\text { physiological } \\
\text { saline (Control) }\end{array}$} & \multirow[t]{6}{*}{0} & 2 & $120.43 \pm 0.29$ & $19.01 \pm 0.32$ & $0.40 \pm 0.05$ & $2.75 \pm 0.02$ \\
\hline & & 4 & $121.26 \pm 0.46$ & $19.36 \pm 0.10$ & $0.50 \pm 0.05$ & $2.93 \pm 0.08$ \\
\hline & & 6 & $128.44 \pm 0.63$ & $19.16 \pm 0.16$ & $0.40 \pm 0.05$ & $3.0 \mathrm{I} \pm 0.06$ \\
\hline & & 8 & $127.77 \pm \mid .42$ & $18.13 \pm 0.63$ & $0.50 \pm 0.05$ & $3.09 \pm 0.06$ \\
\hline & & 12 & $133.80 \pm 0.47$ & $19.27 \pm 0.33$ & $0.53 \pm 0.08$ & $2.86 \pm 0.09$ \\
\hline & & 24 & $|35.9| \pm 0.49$ & $19.37 \pm 0.64$ & $0.60 \pm 0.05$ & $2.23 \pm 0.06$ \\
\hline \multirow{6}{*}{$\begin{array}{l}\text { Helicia nilagirica } \\
\text { aqueous extract }\end{array}$} & \multirow[t]{6}{*}{175} & 2 & $|20.3| \pm 0.64$ & $20.51 \pm 0.45$ & $0.60 \pm 0.05$ & $3.08 \pm 0.01$ \\
\hline & & 4 & $122.54 \pm 1.05$ & $21.76 \pm 0.24$ & $0.6 I \pm 0.02$ & $3.25 \pm 0.0 \mathrm{I}$ \\
\hline & & 6 & $131.07 \pm 0.36$ & $20.4 I \pm 0.50$ & $0.54 \pm 0.02$ & $3.13 \pm 0.07$ \\
\hline & & 8 & $128.73 \pm 3.33$ & $20.51 \pm 0.38^{*}$ & $0.63 \pm 0.08$ & $3.26 \pm 0.01$ \\
\hline & & 12 & $134.50 \pm 0.33$ & $20.25 \pm 0.22$ & $0.69 \pm 0.05$ & $4.05 \pm 0.02 *$ \\
\hline & & 24 & $134.82 \pm 0.16$ & $21.69 \pm 0.72$ & $0.60 \pm 0.05$ & $2.94 \pm 0.27$ \\
\hline \multirow{6}{*}{ Doxorubucin } & \multirow[t]{6}{*}{0.5} & 2 & $121.78 \pm 0.22$ & $20.02 \pm 0.24$ & $0.53 \pm 0.08$ & $3.15 \pm 0.01$ \\
\hline & & 4 & $|25.7| \pm 0.59$ & $20.38 \pm 0.87 *$ & $0.46 \pm 0.03$ & $3.28 \pm 0.01$ \\
\hline & & 6 & $131.22 \pm 0.46$ & $20.62 \pm 0.14$ & $0.46 \pm 0.03$ & $3.58 \pm 0.20$ \\
\hline & & 8 & $131.21 \pm 1.36$ & $21.14 \pm 0.26 *$ & $0.57 \pm 0.01$ & $3.30 \pm 0.01$ \\
\hline & & 12 & $135.58 \pm 0.32$ & $21.12 \pm 0.11$ & $0.60 \pm 0.05$ & $3.16 \pm 0.01 *$ \\
\hline & & 24 & $135.36 \pm 0.85$ & $21.45 \pm 0.11$ & $0.80 \pm 0.05$ & $3.20 \pm 0.10^{*}$ \\
\hline
\end{tabular}

$*_{p}<0.05$, when treatment groups are compared to spontaneous control group.

No symbol= non-significant. $\mathrm{N}=10$.
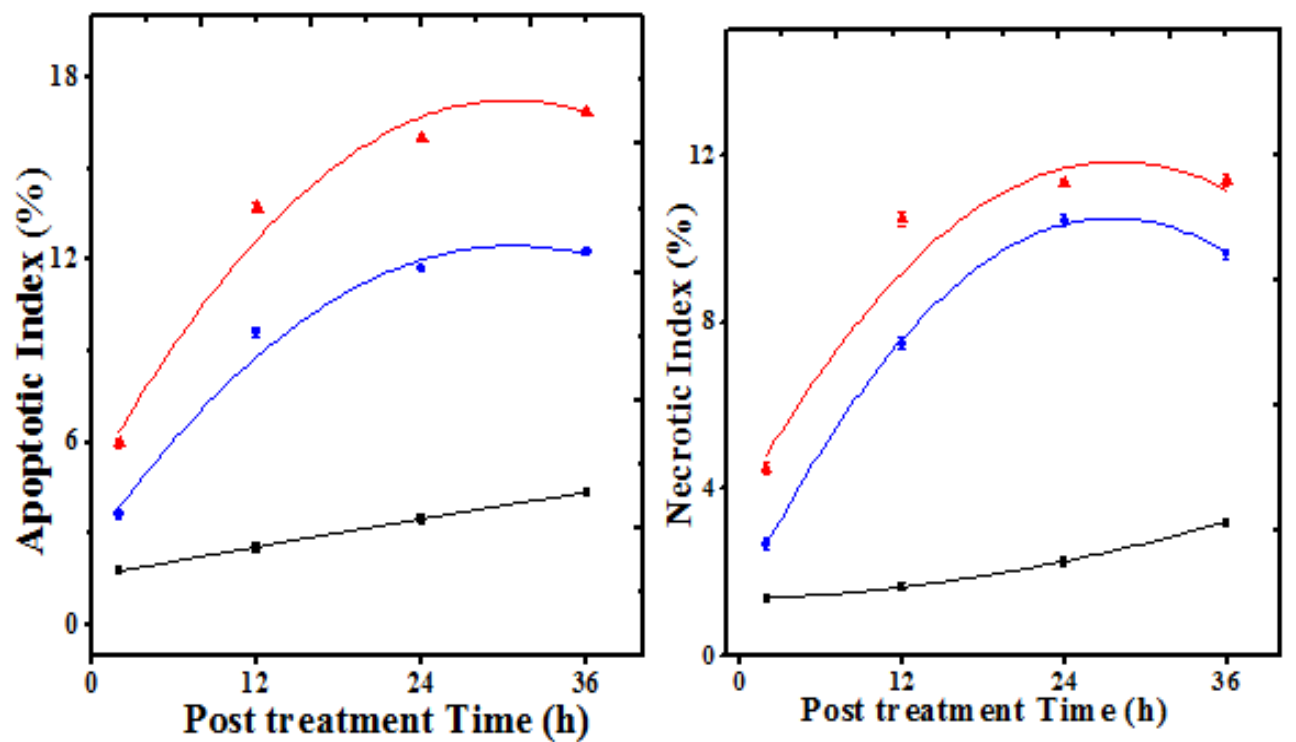

Figure 7 Induction of apoptosis and necrosis in Dalton's lymphoma ascites bearing mice treated with $175 \mathrm{mg} / \mathrm{kg}$ body weight of aqueous extract of Helicia nilagirica or $0.5 \mathrm{mg} / \mathrm{kg}$ body weight of doxorubicin at different post treatment times. Squares: Sterile physiological saline; Circles: Aqueous extract of Helicia nilagirica and Triangles: doxorubicin. Left:Apoptosis and Right: Necrosis. $\mathrm{N}=10$. 

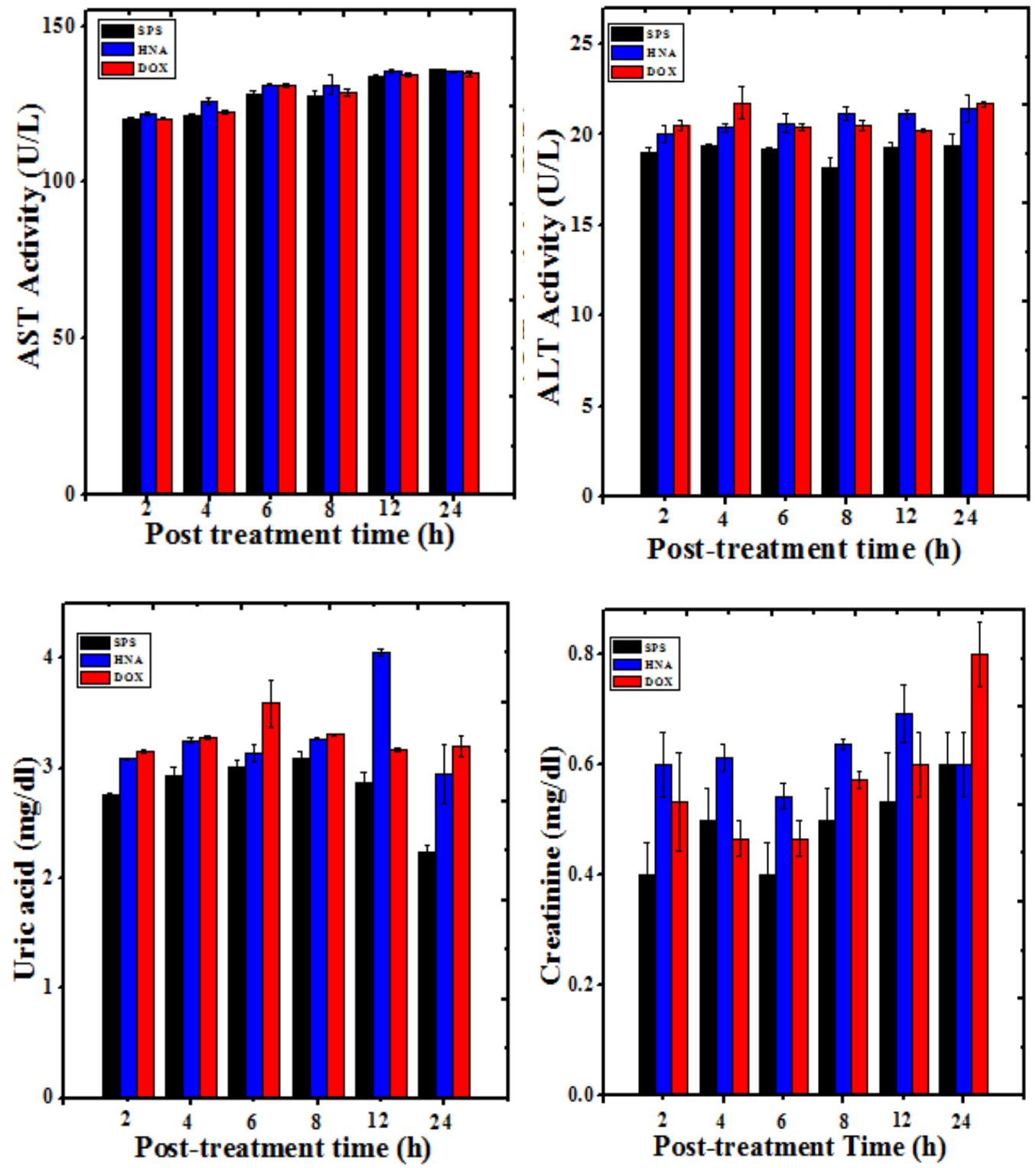

Figure $8 \mathrm{Effect}$ of $175 \mathrm{mg} / \mathrm{kg}$ body weight of aqueous extract of Helicia nilagirica (HNA) or $5 \mathrm{mg} / \mathrm{kg}$ body weight doxorubicin (DOX) on the liver and kidney functions of Dalton's lymphoma bearing mice. The results are Mean $\pm S E M . N=10 . P<0.05$.

\section{Discussion}

The main therapeutic treatment of cancer includes surgery, chemotherapy and radiotherapy and their optimum outcomes are limited due their insensitivity to select tumor cells over normal cells. This results in triggering of systemic toxicity and the development of drug resistance by tumor cells. ${ }^{31,32}$ Therefore, there is a need to focus on the safe and effective therapeutic treatments that can cure cancer without adverse side effects and at the same time avoid development of drug resistance. Herbal medicines have been used all over the world from ancient times as an alternative medicine and they are still used in developing countries to treat and prevent various diseases including cancer. The main advantage of plant derived products over synthetic drugs is the possession of properties which are optimized by evolution for serving different biological functions e.g. binding to specific target proteins or other biomolecules. ${ }^{33,34}$ The inclusion of herbal medicine as an adjuvant therapy in cancer treatment regimen may be able to reduce the toxicity of the drugs against normal cells while increasing the action of drugs by killing the neoplastic cells. ${ }^{35}$ Therefore, the present study was undertaken to investigate the anticancer activity of the aqueous extract of the stem bark of Helicia nilagirica.

The acute toxicity was studied by determining the LD50 of the chloroform, ethanol and aqueous extracts by injecting the different concentrations intraperitoneally according to the guidelines set forth by the OECD. The ethanol extract did not show mortality up to $2 \mathrm{~g} / \mathrm{kg}$ body weight whereas for chloroform and aqueous extracts, the LD50 was found to be $2 \mathrm{~g} / \mathrm{kg}$ and $0.750 \mathrm{~g} / \mathrm{kg}$ body weight, respectively. The reports on the acute toxicity of Helicia nilagirica are unavailable. Similarly, different extract of Colocasia gigantea 
have been reported to have LD50 of $0.2 \mathrm{~g} / \mathrm{kg}$ for ethanol and $0.15 \mathrm{~g} / \mathrm{kg}$ for aqueous and chloroform extracts, respectively after intraperitoneal administration. ${ }^{36}$ The other plants have also been reported to possess low toxicity profiles. ${ }^{37}$ The presence of several chemical molecules may be responsible for low toxicity of chloroform and ethanol extracts of Helicia nilagirica.

The induction of tumor employing DLA cells showed that there was continuous growth of tumor cells in the absence of the extract/s as confirmed by the consistent gain of body weight and all the animals of control group succumbed to death within 21 days showing an average survival time (AST) of 20.66 and median survival time (MST) of 20.5 , whereas with the administration of the extract/s inhibition of tumor growth was observed and the highest increase in survival time has been shown by the aqueous extract at a dose of $175 \mathrm{mg} / \mathrm{kg}$ body weight with an AST of 55 and MST of 86 days, respectively. The HNA has been found to be cytotoxic in HeLa cells treated with its different concentrations earlier. ${ }^{16}$ A similar effect has been observed in DLA mice administered with Colocasia gigantea extract. ${ }^{36}$ Various plant extracts such as Alstonia scholaris, Aphnamixis polystachya, Dillenia pentagyna, and Tinospora cordifolia have also been reported to exert anticancer activity in different in vivo tumor models earlier. ${ }^{37-41}$

The effectiveness of drug against tumor cells could be tested by the presence of micronuclei formed during cell division by acentric fragment or lagging chromosome/s indicating the presence of DNA damage. The aqueous extract of Helicia nilagirica at a dose of $175 \mathrm{mg} /$ $\mathrm{kg}$ body weight showed an increase in micronuclei in a time dependent manner and the numbers of micronuclei bearing cells were highest at $24 \mathrm{~h}$ posttreatment which declined thereafter. An identical observation has been reported in DLA cells treated with Colocasia gigantea extract. ${ }^{36}$ The formation of micronuclei as well as nucleoplasmic bridges (NPB) could be used as a biomarker for the presence of DNA damage, chromosome rearrangement and genotoxicity ${ }^{42,43}$ The presence of micronuclei in the tumor cell being tested could be an indication of DNA damage caused by the $H$. nilagirica extract and may have been the principal contributor to tumor cell kill as micronuclei bearing cells are dying cells. ${ }^{44}$ Some medicinal plants and natural products have also been reported to induce micronuclei leading to the killing of tumor cells. ${ }^{44-46}$

The induction of apoptosis in neoplastic cells is needed to reduce their proliferation through activation of $\mathrm{p} 53$ pathway or other apoptotic pathways. ${ }^{47}$ The treatment of DLA mice with the $175 \mathrm{mg} /$ $\mathrm{kg} \mathrm{b}$. wt. HNA induced apoptosis in a time dependent manner leading to the formation of cell shrinkage, membrane blebbing, chromatin condensation and nuclear fragmentation. Other plant extracts have been reported to inflict cell death by inducing apoptosis in vivo and in vitro. ${ }^{36,48-50}$

The administration of HNA ( $175 \mathrm{mg} / \mathrm{kg}$ b. wt.) for nine consecutive days was found to be safe as it did not alter the level of aspartate aminotransferase (AST), alanine aminotransferase (ALT), creatinine and uric acid significantly even though there was a slight elevation in ALT and uric acid level but these changes were within the normal level. ${ }^{51,52}$ Likewise, treatment of DLA mice with Colocasia gigantea extract has been reported to be non- toxic by retaining the levels of aspartic acid transaminase, alanine aminotransferase, creatinine and uric acid within normal range at different post treatment times in the liver and kidney. ${ }^{36}$
The exact mechanism by which the aqueous extract of $H$. nilagirica stem bark exerted its cytotoxic effect on DLA cells is not clearly understood, however, induction of micronuclei formation and apoptosis in tumor cells indicates that the cell killing process involved DNA damage followed by the apoptosis. The HNA may have reduced the glutathione, glutathione, peroxidase, superoxide dismutase and catalase levels and increased the lipid peroxidation resulting in an effective cell kill. The HNA treatment has been found to reduce the activities of glutathione peroxidase, catalase and superoxide dismutase and glutathione contents accompanied by a rise in the lipid peroxidation. ${ }^{16}$ Induction of apoptosis by HNA may be due to the activation of caspases. The HNA might be able to suppress the expression of $\mathrm{Bcl}_{\mathrm{xL}}$, survivin, IAP, c-FLIP, IKK and NF- $\mathrm{kB}$ or upregulate the levels of apoptotic protein such as Bax leading to the increased mortality of cancer cells at molecular level. A similar mechanism has been reported earlier on black garlic extract. ${ }^{53}$ In addition many other unkown factors might have also contributed to the cytotoxic action of the HNA, which makes it necessary to carry out further investigations on the underlying cause of cytotoxicity against cancer cells.

\section{Conclusions}

The HNA has regressed tumors and increased tumor free survivors beyond 120 days. The tumor cell killing effect of HNA may be due to the induction of DNA damage in the form of micronuclei and triggering of apoptosis. It may have also reduced the level of glutathione peroxidase, catalase, superoxide dismutase and glutathione that may have elevated the oxidative stress and induced different types of lesions in the cells leading to effective tumor cell kill. This would have also been possible due to rise in the lipid peroxidation. At molecular level the HNA may have suppressed the activation of NF- $\mathrm{kB}, \mathrm{COX}-$ II, $\mathrm{Bcl}_{\mathrm{xL}}$, survivin, IAP, c-FLIP, and $\mathrm{Nrf2}$ that may have led to the effective cell kill.

\section{Acknowledgements}

The authors are thankful to the Department of Biotechnology, and University Grants Commission Government of India, New Delhi for providing financial assistance to carry out this study.

\section{Conflict of interest}

The authors have no Conflict of interest statement to declare.

\section{References}

1. IARC. World Cancer Report 2014. BW Stewart, CP Wild, editors. France, Cedex: IARC; 2017.

2. Siegel R L, Miller KD, Jemal A. Cancer statistics, 2017. CA Cancer J Clin. 2017;67(1):7-30.

3. Barh D. Dietary Phytochemicals: a Promise to Chemoprevention. Advanced Biotech. 2005;8:21-23.

4. Sumner J. The Natural History of Medicinal Plants. London: Timber Press; 2000.

5. Newman DJ, Cragg GM. Natural Products as Sources of New Drugs from 1981 to 2014. J Nat Products. 2016;79(3):629-661.

6. Kinghorn AD, de Blanco EJC, Lucas DM, et al. Discovery of anticancer agents of diverse natural origin. Pure Appl Chem. 2009;81(6):1051-1063. 
7. Duflos A, Kruczynski A, Barret JM. Novel aspects of natural and modified vinca alkaloids. Curr Med Chem Anticancer Agents. 2002;2(1):55-70.

8. Jordan MA, Wilson L. Microtubules as a target for anticancer drugs. Nature Rev Cancer. 2004;4(4):253-265.

9. Erba E, Ubezio P, Colombo T, et al. Flow-cytometric analysis of DNA distribution after VP16-213 treatment of Lewis lung carcinoma. Cancer Chemother Pharmacol. 1983;10(3):208-211.

10. O’Dwyer PJ, Leyland-Jones B, Alonso MT, et al. Etoposide (VP16-213): Current status of an active anticancer drug. $N$ Engl J Med 312: 1985;312(11):692-700.

11. Rowinsky EK. Paclitaxel pharmacology and other tumor types. Semin Oncol. 1997;24(6 Suppl 19):S19-1-S19-12.

12. Zasadil LM, Andersen KA, Yeum D, et al. Cytotoxicity of paclitaxel in breast cancer is due to chromosome missegregation on multipolar spindles. Sci Transl Med. 2014;6(229):229-243.

13. Kamal A, Ali Hussaini SM, Rahim A, et al. Podophyllotoxin derivatives: a patent review (2012 - 2014). Expert Opin Ther Patents. 2015;25(9):1025-1034.

14. Khamyong S, Lykke AM, Seramethakun D, et al. Species composition and vegetation structure of an upper montane forest at the summit of Mt. Doi Inthanon, Thailand. Nord J Bot. 2004;23(1):83-97.

15. Sawmliana M. The book of Mizoram Plants. 1st ed. Aizawl: Lois Bet; 2003.

16. Zoremsiami J, Jagetia GC. Evaluation of the cytotoxic effects of Helicia nilagirica Bedd in vitro. Int J Sci Res. 2017;6(9):497-502.

17. Chauhan AS. Ethnobotanical Studies in Sikkim Himalaya. Proceedings of national seminar on traditional knowledge based on herbal medicines and plant resources of north-east India. National Institute of Science Communication and Information Resources. New Delhi: CISR; 2004 p. 200-204.

18. Lalawmpuii PC, Malsawmtluangi C, Vanlalruata R, et al. Evaluation of anti-inflammatory activity of Helicia nilagirica Bedd on cotton pelletinduced granuloma in rats. Int J Pharm Pharm Sci. 2016;8(7):455-456.

19. Geran RI, Greenberg NH, Mac Donald MM, et al. Protocols for screening chemical agents and natural products against animal tumors and other biological systems. Cancer Chemotherapy Reports. 1972;3(2):1-85.

20. Nias AH. Radiation biology. In: Sikora K, Halnan KE, editors. London: Chapman \& Hall Medical; 1990. p. 53-75.

21. Fenech M, Morley AA. Measurement of micronuclei in lymphocytes. Mutat Res. 1985;147(1-2):29-36.

22. Kirsch-Volders M, Sofuni T, Aardema M, et al. Report from the in vitro micronucleus assay working group. Mutat Res. 2003;540(2):153-163.

23. Fenech M, Chang WP, Kirsch-Volders M, et al. HUMN project: detailed description of the scoring criteria for the cytokinesis-block micronucleus assay using isolated human lymphocyte cultures. Mutat Res. 2003;534(1):65-75.

24. Kasibhatla S, Amarante-Mendes GP, Finucane D, Brunner T, BossyWetzel E, Green DR. 2006. Acridine orange/ethidium bromide (AO/ EB) staining to detect apoptosis. Cold Spring Harbor Protocols. 2006;3:pdb-rot4493.

25. Bradford MM. A rapid and sensitive method for the quantitation of microgram quantities of protein utilizing the principle of protein-dye binding. Anal Biochem. 1976;72(1-2):248-254.
26. Moron MS, Depierre JW, Mannervik B. Levels of glutathione, glutathione reductase and glutathione S-transferase activities in rat lung and liver. Biochim Biophys Acta. 1979;582(1):67-78.

27. Habig WH, Pabst MJ, Jakoby WB. Glutathione S-transferases. The first enzymatic step in mercapturic acid formation. $J$ Biol Chem. 1974;249(22):7130-7139.

28. Aebi H. Catalase in vitro. Methods Enzymol. 1984;105:121-126.

29. Fried R. Enzymatic and non-enzymatic assay of superoxide dismutase. Biochimie. 1975;57(5):657-660.

30. Buege JA, Aust SD. Microsomal lipid peroxidation. Methods Enzymol. 1978;30:302-310.

31. Xu G, McLeod HL. Strategies for enzyme/prodrug cancer therapy. Clin Cancer Res. 2001;7:3314-3324.

32. Housman G, Byler S, Heerboth S, et al. Drug resistance in cancer: an overview. Cancers. 2014;6(3):1769-1792.

33. Hunter P. Harnessing nature's wisdom. Turning to nature for inspiration and avoiding her follies. EMBO Rep. 2008;9(9):838-840.

34. Appendino G, Fontana G, Pollastro F. Natural products drug discovery. In: Liu HW, Mander L, editors. Comprehensive Natural Products II. Elsevier: Oxford; 2010. p. 205-236.

35. Tannock IF. Treatment of cancer with radiation and drugs. J Clin Oncol. 1996;14:3156-3174.

36. Devi NB, Jagetia GC. Antitumor activity of different extracts of Colocasia gigantea in Dalton's lymphoma transplanted Swiss Albino mice. Int Res J Pharmaceut Biosci (IRJPBS). 2017;4(4):52-82.

37. Jagetia GC, Baliga MS. Effect of Alstonia scholaris in enhancing the anticancer activity of berberine in the Ehrlich ascites carcinoma bearing mice. Food. 2004;7(2):235-244.

38. Jagetia GC, Rao SK. Evaluation of the antineoplastic activity of guduchi (Tinospora cordifolia) in Ehrlich ascites carcinoma bearing mice. Biol Pharmaceut Bull. 2006;29:460-466.

39. Rosangkima T, Rongpi T, Prasad SB. Role of glutathione and glutathione-related enzymes in the antitumor activity of Dillenia pentagyna in Dalton's lymphoma-bearing mice. Int $J$ Cancer Res. 2008;4(3):92-102.

40. Jagetia GC, Venkatesha VA. Preclinical Determination of the Anticancer Activity of Rohituka (Aphanamixis polystachya) in Ehrlich Ascites Tumor-Bearing Mice. Med Arom Plant Sci Biotech. 2012;6:42-51.

41. Jagetia GC, Baliga MS. Preclinical Investigation of Anticancer Potential of Hydroalcoholic Stem Bark Extract of Alstonia scholaris in Ehrlich Ascites Carcinoma Transplanted in Swiss Albino Mice. J Altern Med Res. 2016;2(2):115

42. Fenech M. Chromosomal biomarkers of genomic instability relevant to cancer. Drugs Discovery Today. 2002;7(22):1128-1137.

43. Thomas P, Umegaki K, Fenech M. Nucleoplasmic bridges are a sensitive measure of chromosome rearrangement in the cytokinesisblock micronucleus assay. Mutagenesis. 2003;18(2):187-194.

44. Jagetia A, Jagetia GC, Jha S. Naringin, a grape fruit flavanone, protects V79 cells against the bleomycin-induced genotoxicity and decline in the survival. J Appl Toxicol. 2007;27(2):122-132.

45. Jagetia GC, Venkatesh P. Bael, Aegle marmelos (L.) Correa, an Indian medicinal plant protects V79 cells against the genotoxic effect of doxorubicin. Int J Genet Mol Biol. 2015;7(5):32-46. 
46. Jagetia GC, Venkatesha VA. Determination of antineoplastic activity of rohituka, Aphanamixis polystachya (Wall.) R. N. Parker in HeLa cells: Correlation with clonogenicity and DNA damage. Int $J$ Complmen Altern Med. 2016;3(4): 00083.

47. Lowe SW, Lin WA. Apoptosis in cancer. Carcinogenesis. 2000;21(3):485-495

48. Cheng YL, Lee SC, Harn HJ, et al. The extract of Hibiscus syriacus inducing apoptosis by activating p53 and AIF in human lung cancer cells. Am J Chinese Med. 2008;36(1):171.

49. Aghbali A, Abbasabadi FM, Delazar A, et al. Induction of Apoptosis and Cytotoxic Activities of Iranian Orthodox Black Tea Extract (BTE) Using in vitro Models. Adv Pharmaceut Bull. 2014;4(3):255-260.
50. Bhatia D, Mandal A, Nevo E, et al. Apoptosis-inducing effects of extracts from desert plants in HepG2 human hepatocarcinoma cells. Asian Pacific J Trop Biomed. 2015;5(2):87-92.

51. Reitman S. Frankel S. A colorimetric method for the determination of serum glutamic oxalacetic and glutamic pyruvic transaminases. $\mathrm{Am} J$ Clin Pathol. 1957;28(1):56-63.

52. Fossati P, Prencipe L, Berti G. Use of 3, 5-dichloro-2hydroxybenzenesulfonic acid/4-aminophenazone chromogenic system in direct enzymic assay of uric acid in serum and urine. Clinical Chem. 1980;26(2):227-231.

53. Park C, Park S, Chung YH, et al. Induction of apoptosis by a hexane extract of aged black garlic in the human leukemic U937 cells. Nutr Res Pract. 2014;8(2):132-137. 